\title{
Pengaruh Latihan Fisik Teratur terhadap Kadar Glukosa Darah dan Hubungannya dengan Kadar Testosteron Total pada Tikus Model Diabetes
}

\author{
Zulkarnain, ${ }^{1}$ Darma Satria, ${ }^{2}$ T. M. Yus, ${ }^{3}$ Soraya Rezeki ${ }^{4}$ \\ ${ }^{1}$ Bagian Fisiologi Fakultas Kedokteran Universitas Syiah Kuala, ${ }^{2}$ Bagian Patologi Anatomi Fakultas Kedokteran \\ Universitas Syiah Kuala, ${ }^{3}$ Bagian Ilmu Gizi Fakultas Kedokteran Universitas Syiah Kuala, ${ }^{4}$ Bagian Parasitologi \\ Fakultas Kedokteran Universitas Syiah Kuala
}

\begin{abstract}
Abstrak
Kondisi hiperglikemia kronik pada diabetes melitus dapat mengganggu fungsi reproduksi, salah satunya adalah penurunan kadar testosteron total. Latihan fisik teratur merupakan salah satu pendekatan nonfarmakologi untuk menurunkan kadar glukosa darah dan memperbaiki kadar testosteron total pada diabetes melitus. Penelitian bertujuan untuk menentukan pengaruh latihan fisik teratur terhadap kadar glukosa darah puasa (GDP) dan hubungannya dengan kadar testosteron total pada tikus diabetes melitus. Penelitian eksperimental murni rancangan pre-postest with control group design dilakukan di Laboratorium Fisiologi, Fakultas Kedokteran dan Laboratorium Riset, Fakultas Kedokteran Hewan Universitas Syiah Kuala, Banda Aceh, periode Juni-Oktober 2013. Lima belas tikus putih jantan Sprague-Dawley dibagi tiga kelompok: (I) kontrol, (II) kelompok diabetes melitus, dan (III) kelompok diabetes melitus yang diberi latihan fisik. Latihan fisik dilakukan pada intensitas ringan-sedang selama 9 minggu sesuai protokol Souza. Kadar GDP diukur setiap 3 minggu selama latihan fisik dan perubahannya dibandingkan antarkelompok. Kadar testosteron total diukur setelah 9 minggu menjalani latihan fisik. Kadar testosteron total rata-rata tikus diabetes melitus yang diberi latihan fisik berbeda dibanding dengan tanpa latihan fisik ( $\mathrm{p}=0,032)$. Terdapat korelasi negatif antara perubahan kadar GDP dan kadar testosteron total ( $\mathrm{p}=0,007$; korelasi Pearson - 0,661). Simpulan, latihan fisik teratur dengan intensitas ringan-sedang dapat menurunkan kadar glukosa darah dan memperbaiki kadar testosteron total pada tikus diabetes. [MKB. 2015;47(1):16-21]
\end{abstract}

Kata kunci: Hiperglikemia, kadar testosteron total, latihan fisik teratur

\section{Effects of Regular Physical Exercise on Blood Glucose Levels and Its Relationship to Total Testosterone Levels in Diabetic Rats}

\begin{abstract}
A state of chronic hyperglycemia in diabetes mellitus may cause dysfunction of the reproductive system; one of these is the decrease in total testosterone level. A regular physical exercise is one of the non-pharmacological approaches to reduce blood glucose level and improve total testosterone level in diabetes mellitus. The study was aimed to determine the effects of regular physical exercise on fasting blood glucose (FBG) levels and its relationship to total testosterone levels in diabetic rats. Pre-postest experimental study with control group design, was conducted during June-October 2013 at Physiology Laboratory of Medical Faculty and Research Laboratory of Veterinary Medicine, Syiah Kuala University, Banda Aceh. Fifteen male Sprague-Dawley rats were divided into three groups: (I) control, (II) sedentary diabetic, and (III) exercise diabetic. The physical exercise was performed at low-moderate intensity for nine weeks according to Souza's protocol. The levels of blood glucose were measured every three weeks during the regular physical exercise; the changes of blood glucose level were compared between groups, whereas the levels of total testosterone were measured after nine weeks of regular physical exercise. The mean of total testosterone level was different $(\mathrm{p}=0.032)$ between the group with physical exercise and without physical exercise. There was a negative correlation between changes in FBG levels and total testosterone levels $(\mathrm{p}=0.007$, Pearson correlation -0.661). In conclusion, regular physical exercise with low-moderate intensity reduces blood glucose levels and improves total testosterone levels in diabetic rats. [MKB. 2015;47(1):16-21]
\end{abstract}

Key words: Hyperglycemia, regular physical exercise, total testosterone level

Korespondensi: Zulkarnain, dr., MSc, Bagian Fisiologi Fakultas Kedokteran Universitas Syiah Kuala Banda Aceh, mobile 085277728024, e-mail: zoelcyber@gmail.com 


\section{Pendahuluan}

Morbiditas dan mortalitas kasus diabetes melitus terus meningkat seiring dengan komplikasi yang ditimbulkan pada berbagai organ. ${ }^{1}$ Gangguan fungsi organ reproduksi pria merupakan salah satu komplikasi yang telah banyak dilaporkan pada penderita diabetes melitus dan dikatakan sebagai salah satu faktor penyebab infertilitas pada pria. ${ }^{2}$ Dhindsa $\mathrm{dkk}^{3}$ dan Kianifard $\mathrm{dkk}^{4}$ menemukan penurunan hormon testosteron dan gangguan spermatogenesis pada diabetes melitus sangat berkaitan erat dengan peningkatan kadar glukosa darah yang tidak terkontrol di dalam sirkulasi. Keadaan hiperglikemia tersebut juga dapat mengganggu aksis hipotalamus-hipofisisgonad (HHG) serta secara lokal menimbulkan kerusakan terhadap proliferasi sel Leydig dan sel Sertoli. Sel Leydig dan sel Sertoli merupakan sel-sel fungsional intratestikular yang memiliki peran dalam biosintesis testosteron dan proses spermatogenesis.

Perbaikan konsentrasi glukosa darah dan testosteron total sangat penting dilakukan untuk meningkatkan kualitas hidup penderita diabetes melitus dan juga mencegah kerusakan pada organ reproduksi pria. Pitteloud dkk. ${ }^{5}$ mengemukakan bahwa peningkatan sekresi testosteron total pada diabetes melitus berkorelasi positif dengan perbaikan sensitivitas insulin dan kadar glukosa darah dan demikian juga sebaliknya. Pemberian testosteron secara eksogen penderita diabetes melitus sudah lama dilakukan namun banyak menimbulkan kontroversial karena pemberian dalam jangka waktu yang lama diduga berpotensi meningkatkan risiko kanker prostat serta dapat menyebabkan terganggunya spermatogenesis. ${ }^{6,7}$ Oleh karena itu, diperlukan pendekatan lain yang lebih aman dalam pengelolaan komplikasi diabetes melitus pada sistem reproduksi pria.

Pendekatan nonfarmakologi seperti latihan fisik teratur dan terukur telah dilaporkan dapat memperbaiki gangguan glukosa darah dan juga sensitivitas insulin pada diabetes melitus serta meningkatkan kadar testosteron pada intensitas tertentu. ${ }^{8,9}$ Peneliti tertarik untuk mempelajari lebih lanjut pengaruh perubahan kadar glukosa darah puasa terhadap kadar testosteron total serta menganalisis hubungan kedua variabel tersebut pada tikus diabetes melitus sesudah pemberian latihan fisik teratur dan terukur.

\section{Metode}

Penelitian eksperimental murni menggunakan pre-postest with control group design telah dilakukan selama periode bulan Juni sampai dengan Oktober 2013 di Laboratorium Fisiologi, Fakultas Kedokteran dan Laboratorium Riset, Fakultas Kedokteran Hewan Universitas Syiah Kuala, Banda Aceh. Penelitian ini menggunakan 15 ekor tikus putih jantan jenis Sprague Dawley berumur 11-12 minggu yang diinduksi STZ (streptozotocin) sebagai model tikus diabetes melitus. Tikus dibagi dalam 3 kelompok masingmasing terdiriatas 5 ekor tikus, yaitu (I) kelompok kontrol, (II) tikus diabetes melitus induksi STZ, dan (III) kelompok tikus diabetes melitus yang diberi latihan fisik teratur. Pemeriksaan kadar glukosa darah puasa (GDP) dilakukan dengan memakai metode glucose oxidase-peroxidase (GOD-POD), penapisan perubahan GDP dengan alat cek glukosa Easy touch $^{\circledR}$, dan pengukuran kadar testosteron total dilakukan dengan teknik ELISA.

Subjek penelitian diaklimatisasi selama tujuh hari sebelum perlakuan pada suhu ruangan berkisar $20-25^{\circ} \mathrm{C}$, dipertahankan dalam siklus 12 jam terang dan 12 jam gelap, diberi pakan standar dan minum ad libitum. Setelah adaptasi selesai, semua tikus ditimbang dan diperiksa kadar GDP sebagai parameter nilai basal. Tikus diambil secara acak untuk dijadikan sebagai tikus model diabetes melitus dengan memakai induksi STZ dosis tunggal $35 \mathrm{mg} / \mathrm{kg}$ dalam $0,1 \mathrm{M}$ bufer sitrat $\mathrm{pH} 4,5$ secara intraperitoneal. ${ }^{10}$ Tiga hari setelah induksi STZ dilakukan pemeriksaan kadar GDP. Hewan model dinyatakan sebagai tikus diabetes melitus apabila memiliki kadar GDP $>145 \mathrm{mg} / \mathrm{dL}^{10}$ Hewan model yang telah dianggap diabetes melitus akan dibiarkan dalam kondisi hiperglikemia tanpa pemberian terapi. Pada hari ke-24 diperiksakan kembali kadar GDP. Selanjutnya tikus yang bertahan dalam kondisi hiperglikemia dapat dikelompokkan secara acak menjadi dua kelompok perlakuan, yaitu tikus diabetes melitus tanpa latihan fisik (II) dan tikus diabetes melitus yang diberi latihan fisik teratur (III).

Latihan fisik teratur dan terukur diberikan pada hari ke-25 terhadap kelompok III selama 9 minggu pada intensitas ringan-sedang dengan mempergunakan treadmill khusus tikus (sudut kemiringan $0^{\circ}$ ) sesuai protokol penelitian Souza dkk. ${ }^{11}$ Kelompok II dibiarkan dalam kondisi hiperglikemia tanpa pemberian terapi serta akan diletakkan dalam posisi diam pada alat treadmill. Latihan fisik dilakukan dalam dua tahapan, yaitu tahap adaptasi (awal) dan tahap latihan inti. Pada tahap adaptasi, latihan diberikan setiap hari selama 7 hari dengan kecepatan 5 meter/menit 


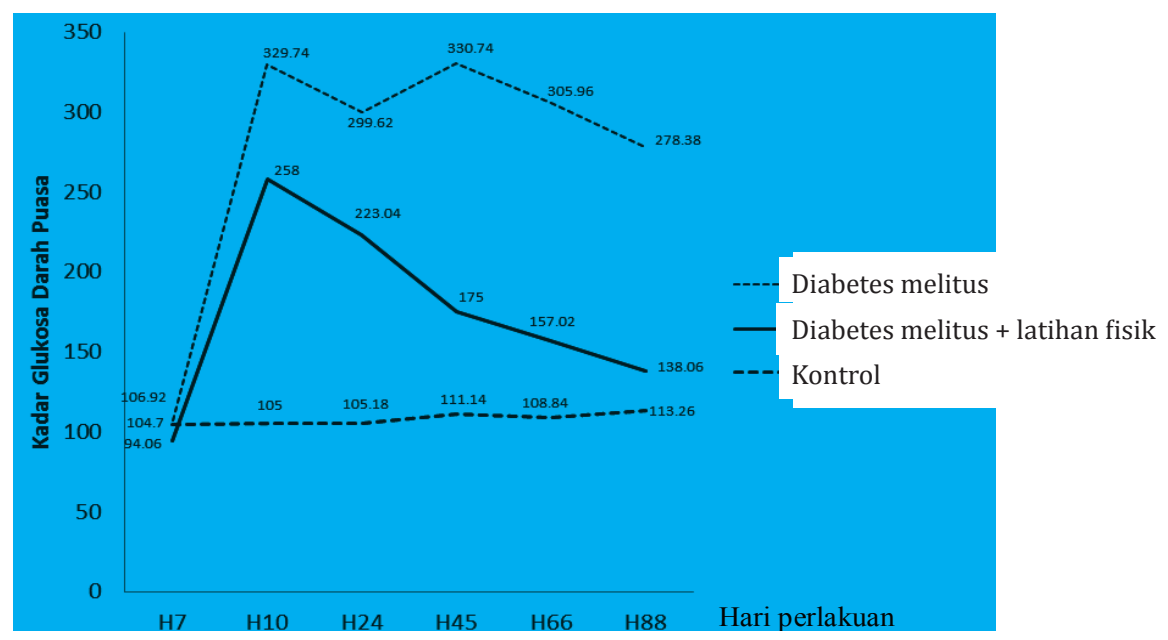

\section{Gambar 1 Kadar Glukosa Darah Puasa Rata-rata pada Setiap Kelompok Penelitian}

dan durasi 10 menit/hari. Tahapan latihan inti dilakukan pada minggu kedua sampai dengan minggu kesembilan dengan dosis latihan yang berbeda. Intensitas latihan inti ini ditingkatkan secara bertahap setiap minggunya yang dimulai dengan kecepatan 5 meter/menit sampai 20 meter/menit selama 60 menit/hari. Frekuensi latihan inti yang diberikan sebanyak 5 kali dalam setiap minggu. Tikus yang diberikan latihan inti harus menjalani pemanasan dan pendinginan selama 10 menit. ${ }^{11}$ Pemeriksaan GDP dilakukan juga pada minggu ke-3 dan ke-6 selama latihan fisik berlangsung. Pengukuran kadar testosteron total hanya dilakukan satu kali pada hari ke-88 setelah perlakuan latihan fisik yang terakhir. Selanjutnya, semua tikus dibius dengan ketamin sebelum diterminasi.

Data hasil pengukuran kadar glukosa darah puasa (GDP) untuk setiap kelompok dinyatakan dalam rata-rata \pm SEM (standard error of mean). Perubahan konsentrasi glukosa darah adalah kadar GDP rata-rata yang diperoleh mulai hari ke-10 sampai hari ke-88 dikurangi dengan nilai GDP basal. Analisis data dilakukan dengan menggunakan one way ANOVA dan dilanjutkan analisis post-hoc. Uji korelasi Pearson digunakan untuk menilai korelasi antara perubahan kadar GDP terhadap kadar testosteron total pada tikus induksi STZ yang diberi latihan fisik teratur. Perbedaan bermakna secara statistik diperoleh apabila nilai $\mathrm{p}<0,05$ dan tingkat kepercayaan $95 \%$.

\section{Hasil}

Hasil penelitian memperlihatkan bahwa kondisi hiperglikemia yang menetap pada tikus model diabetes melitus pascainduksi STZ dosis rendah (35 mg/kgBB) belum menimbulkan pemulihan secara reversibel sampai diterminasi pada hari ke-88 ( \pm 12 minggu) (Gambar 1).

Perubahan glukosa darah dinyatakan sebagai kadar rata-rata GDP yang diperoleh mulai hari ke10 sampai hari ke-88 dikurangi dengan nilai GDP basal. Tabel 1 menunjukkan bahwa perubahan kadar GDP yang terjadi pada kelompok diabetes melitus lebih lambat dan tidak terkontrol dengan baik apabila dibandingkan dengan kelompok lainnya dengan rata-rata $201,97 \pm 41,63 \mathrm{mg} / \mathrm{dL}$.

Tabel 1 Perubahan Kadar GDP pada Kelompok Kontrol, Kelompok Diabetes Melitus, dan Kelompok Diabetes Melitus yang Diberi Latihan Fisik

\begin{tabular}{llcc}
\hline & \multicolumn{1}{c}{ Kelompok } & n & Rata-rata \pm SEM (mg/dL) \\
\hline Perubahan kadar GDP & I. Kontrol & 5 & $11,70 \pm 2,60$ \\
(GDP-nilai basal rata-rata) & II. Diabetes melitus & 5 & $201,97 \pm 41,63$ \\
& III. Diabetes melitus +latihan fisik & 5 & $96,16 \pm 11,76$ \\
\hline
\end{tabular}

Keterangan: GDP (glukosa darah puasa); SEM (standard error of mean) 
Tabel 2 Kadar Testosteron Total Rata-rata pada Kelompok Tikus Normal, Kelompok STZ, dan Kelompok STZ yang Diberi Latihan Fisik

\begin{tabular}{lccc}
\hline \multicolumn{1}{c}{ Kadar Testosteron Rata-Rata } & n & Rata-rata \pm SEM (mg/dL) & p \\
\hline I. Kontrol & 5 & $1,28 \pm 0,21$ \\
II. Diabetes melitus & 5 & $0,71 \pm 0,15$ & 0,046 \\
III. Diabetes melitus +latihan fisik & 5 & $1,26 \pm 0,08$ & \\
\hline
\end{tabular}

Keterangan: SEM (standard error of mean); LSD (least significant difference); uji one way ANOVA.uji post-hoc LSD: kontrol vs diabetes melitus $p=0,028$; kontrol vs diabetes melitus +latihan fisik $p=0,947$; diabetes melitus vs diabetes melitus+latihan fisik $\mathrm{p}=0,032$

Berbeda halnya pada kelompok diabetes melitus yang diberi latihan fisik $(96,16 \pm 11,76 \mathrm{mg} / \mathrm{dL})$ menunjukkan perubahan GDP yang terjadi lebih stabil dan mengalami perbaikan mendekati nilai normalnya.

Hasil pengukuran kadar testosteron rata-rata yang diperoleh dari setiap kelompok pada hari ke-88 memperlihatkan bahwa kadar testosteron total pada kelompok II (diabetes melitus) lebih rendah dari kelompok I (kontrol) dan kelompok III (diabetes melitus+latihan fisik). Selanjutnya, tidak terdapat perbedaan kadar testosteron total pada kelompok I dengan kelompok III (Tabel 2).

Hasil penelitian didapatkan korelasi yang kuat antara perubahan kadar GDP rata-rata dan kadar testosteron total (korelasi Pearson $-0,661 ; p=0,007)$ (Tabel 3). Nilai korelasi negatif menunjukkan bahwa penurunan kadar GDP setelah latihan fisik dapat meningkatkan kadar testosteron total pada tikus diabetes melitus yang diinduksi STZ dosis rendah.

\section{Pembahasan}

Pada penelitianini didapatkan bahwa latihan fisik intensitas ringan-sedang mampu memperbaiki perubahan konsentrasi GDP pada tikus diabetes melitus yang diinduksi STZ dosis rendah (Tabel 1). Latihan fisik juga meningkatkan metabolisme

Tabel 3 Hasil Analisis Korelasi Pearson

\begin{tabular}{lcc}
\hline & $\begin{array}{c}\text { Testosteron } \\
\text { Total }\end{array}$ \\
\hline $\begin{array}{l}\text { Perubahan kadar } \\
\text { GDP }\end{array}$ & $\mathrm{r}^{*}$ & $-0,661$ \\
& $\mathrm{p}$ & 0,007 \\
& $\mathrm{n}$ & 15 \\
\hline
\end{tabular}

Keterangan: GDP (glukosa darah puasa) *Uji korelasi Pearson otot dan penggunaan glukosa pada jaringan yang berkontraksi sehingga tidak terjadi akumulasi glukosa yang berlebihan dalam sirkulasi sistemik. Penelitian Coskun dkk. ${ }^{12}$ telah memperlihatkan bahwa tikus diabetes melitus yang diberi latihan fisik teratur (berenang) selama delapan minggu dapat melindungi dan juga mencegah kerusakan sel $\beta$ pankreas akibat toksisitas pascainduksi oleh streptozotocin sehingga dapat memperbaiki kadar glukosa darah.

Latihan fisik dapat memperbaiki sensitivitas insulin sehingga memudahkan glukosa masuk ke dalam sel serta memenuhi kebutuhan otot skelet selama proses kontraksi. ${ }^{13}$ Menurut Sato dkk., ${ }^{14}$ latihan fisik dapat memicu penggunaan glukosa darah dan asam lemak bebas dalam otot sehingga kadar glukosa darah menjadi menurun dan dapat terkontrol dengan baik pada pasien diabetes melitus. Perbaikan kadar glukosa darah akibat peningkatan derajat sensitivitas insulin berhubungan erat dengan penurunan massa lemak di dalam tubuh. ${ }^{15}$ Penurunan massa lemak tubuh sesudah latihan fisik akan mengurangi jumlah molekul kolesterol di dalam membran lipid bilayer sehingga memengaruhi fluiditas membran sel dan meningkatkan respons reseptor insulin di permukaan sel. Penelitian Boor dkk. ${ }^{16}$ yang memberi perlakuan latihan fisik pada tikus obese Zucker rats selama 10 minggu dengan intensitas sedang tidak menunjukkan perubahan pada glukosa darahnya. ${ }^{16}$ Metabolisme glukosa selama perlakuan latihan fisik sangat bergantung pada jenis serta intensitas latihan fisik yang diberikan. ${ }^{8}$ Peneliti berasumsi perbedaan hasil penelitian tersebut dapat dipengaruhi oleh jenis hewan model yang digunakan, intensitas, dan durasi latihan fisik yang diberikan.

Hasil penelitian juga didapatkan perbedaaan kadar testosteron total bermakna pada tikus diabetes melitus dibanding dengan tikus kontrol (Tabel 2). Kerusakan yang ditimbulkan akibat keadaan hiperglikemia kronik apabila dibiarkan 
akan bermanifestasi terhadap gangguan proses biosintesis dan juga sekresi hormon. Gangguan sekresi testosteron pada diabetes melitus terjadi akibat kelainan pada aksis hipotalamus-hipofisisgonad sehingga mengganggu regulasi hormon tersebut. ${ }^{17}$ Selain itu, hiperglikemia kronik juga dapat menyebabkan kerusakan secara lokal pada sel-sel Leydig dan enzim-enzim steroidogenik yang dibutuhkan dalam biosintesis testosteron intratestikular. ${ }^{18}$

Latihan fisik dengan intensitas ringan hingga sedang pada penelitian ini mampu meregulasi dan juga mempertahankan konsentrasi hormon testosteron pada tikus dengan diabetes melitus mendekati konsentrasi pada tikus kontrol (Tabel 2). Latihan fisik yang teratur akan berperan penting untuk memperbaiki fungsi homeostasis sesuai dengan kebutuhan tubuh, termasuk juga keseimbangan hormonal. Beberapa penelitian telah memperlihatkan bahwa latihan fisik teratur berpengaruh positif pada perubahan fungsi endokrin, salah satunya adalah meningkatkan kadar testosteron total. ${ }^{9,19}$ Pendekatan secara nonfarmakologi tersebut akan bermanfaat pada penderita yang mengalami disfungsi seksual dan penurunan libido akibat komplikasi diabetes melitus. Penelitian Aizawa dkk. ${ }^{19}$ pada tikus-tikus jantan yang diberi latihan treadmill intensitas 30 $\mathrm{m} /$ menit selama tiga puluh menit dilaporkan mampu meningkatkan konsentrasi testosteron dan enzim 3 $\beta$-HSD/17 $\beta$ HSD dalam otot skeletal. Peneliti berasumsi bahwa peningkatan kadar hormon tersebut dalam otot skelet akan ikut memengaruhi kadar testosteron total sirkulasi namun perubahan hormonal tersebut bervariasi setiap individu dipengaruhi oleh jenis latihan fisik, durasi, dan intensitas yang diberikan. ${ }^{9}$

Mekanisme perbaikankonsentrasitestosteron tikus diabetes melitus setelah latihan fisik belum dapat dijelaskan secara pasti. Peneliti berasumsi perbaikan hormon tersebut dipengaruhi oleh perubahan kadar GDP yang dievaluasi dalam waktu tertentu. Penelitian Pitteloud dkk. ${ }^{5}$ yang mengevaluasi konsentrasi testosteron, estradiol, kolesterol total, HDL, dan trigliserida sebelum dan sesudah pemberian terapi insulin pada lakilaki obesitas dan penderita DM tipe 2 menyatakan bahwa peningkatan sekresi hormon testosteron berkorelasi positif dengan perbaikan sensitivitas insulin, demikian juga sebaliknya. Pascalatihan fisik terjadi peningkatan sensitivitas insulin yang memudahkan glukosa masuk ke dalam sel-sel sehingga mengurangi akumulasi kadar glukosa dalam sirkulasi dan meningkatkan aktivitas sel Leydig untuk menyekresi testosteron.

Hambrecht dkk. ${ }^{20}$ telah melaporkan bahwa peningkatan testosteron total setelah latihan fisik juga terjadi melalui sinyal insulin like growth factor-1 (IGF-1). Latihan fisik aerobic intensitas ringan hingga sedang dapat memicu sekresi IGF1 secara lokal pada otot skelet yang berkontraksi, kemudian dilepaskan ke dalam sirkulasi secara bertahap dan memengaruhi ekspresi di jaringan target lainnya. ${ }^{20}$ Sel Leydig merupakan salah satu target dari IGF-1 sehingga peningkatan IGF-1 dalam sirkulasi selama latihan fisik akan memicu proliferasi serta sekresi testosteron dalam sel Leydig.

Simpulan, latihan fisik yang teratur intensitas ringan-sedang dapat memperbaiki konsentrasi glukosa darah puasa dan dapat mempertahankan kadar testosteron total pada tikus-tikus diabetes melitus. Perubahan kadar glukosa darah puasa pada kondisi tersebut berkorelasi negatif dengan perbaikan kadar testosteron total. Kekurangan pada penelitian ini adalah tidak dilakukannya pengamatan awal terhadap kadar testosteron total sehingga sulit untuk menjelaskan bahwa perbaikan konsentrasi testosteron total tersebut berkorelasi langsung dengan latihan fisik.

\section{Ucapan Terima Kasih}

Ucapan terima kasih ditujukan kepada Direktorat Jenderal Pendidikan Tinggi Kemendikbud yang telah mendanai penelitian ini melalui Lembaga Penelitian Universitas Syiah Kuala Banda Aceh tahun anggaran 2013 Nomor 187/UN11/S/LKPNBP/2013/2013 Tanggal 13 Mei 2013.

\section{Daftar Pustaka}

1. Cade WT. Diabetes-related microvascular and macrovascular diseases in the physical therapy setting. Phys Ther. 2008;88:132235.

2. Mallidis C, Agbaje IM, McClure N, Kliesch S. The influence of diabetes mellitus on male reproductive function: a poorly investigated aspect of male infertility. Urologe A. 2011;50(1):33-7.

3. Dhindsa S, Miller MG, McWhirter CL, Mager DE, Ghanim H, Chauduri A, dkk. Testosterone concentrations in diabetic and non diabetic obese men. Diabetes Care. 2010;33:118692.

4. Kianifard D, Sadrkhanlou RJ, Hasanzadeh S. The ultrastructural changes of the Sertoli and Leydig cells following streptozotocin induced diabetes. Iran J Basic Med Sci. 
2012;15(1):623-35.

5. Pitteloud N, Mootha VK, Dwyer AA, Hardin M, Lee H, Eriksson FK, dkk. Relationship between testosterone level, insulin sensitivity and mitochondrial function in men. Diabetes Care. 2005;28:1636-42.

6. Gaylis FD, Lin DW, Ignatof JM, Amling CL, Tutrone RF, Cosgrove DJ, dkk. Prostate cancer in men using testosterone supplementation. J Urol. 2005;174(2):534-8.

7. Moss JL, Crosnoe LE, Kim ED. Effect of rejuvenation hormones on spermatogenesis. Fertil Steril. 2013;99(7):1814-20.

8. Feo PD, Loreto CD, Ranchelli A, Fatone C, Gambelunghe G, Lucidi P, dkk. Exercise and diabetes. ACTA Biomed. 2006;77(1):14-7.

9. Liu TC, Kuo $\mathrm{CH}$, Wang PS. Exercise and testosterone. Adapt Med. 2009;1(1):26-31.

10. Suryanarayana P, Saraswat M, Mrudula T, Krishna TP, Krishnaswamy K, Reddy GB, dkk. Curcumin and turmeric delay streptozotocininduced diabetic cataract in rats. Invest Ophthalmol Vis Sci. 2005;46:2092-9.

11. Souza SBC, Flues K, Paulini J, Mostarda C, Rodrigues B, Souza LE, dkk. Role of exercise training in cardiovascular autonomic dysfunction and mortality in diabetic ovariectomized rats. Hypertension. 2007;50:786-91.

12. Coskun O, Ocakci A, Bayraktaroglu T, Kanter M. Exercise training prevents and protects streptozotocin induced oxidative stress and $\beta$-cell damage in rat pancreas. Tohoku. J Exp Med. 2004;203:145-54.

13. DiPietro L, Dziura J, Yeckel CW, Neufer PD. Exercise and improved insulin sensitivity in older women: evidence of the enduring benefits of higher intensity training. J Appl Physiol. 2006;100:142-9.
14. Sato $Y$, Nagasaki M, Kubota M, Uno T, Nakai N. Clinical aspects of physical exercise for diabetes/metabolic syndrome. Diabetes Res Clin Pract. 2007;77(1):S87-91.

15. Ryan A, Nicklas BJ. Reductions in plasma cytokine levels with weight loss improve insulin sensitivity in overweight and obese postmenopausal women. Diabetes Care. 2004;27:1699-705.

16. Boor P, Celec P, Behuliak M, Grancic P, Kebis A, Kukan M, dkk. Regular moderate exercise reduces advanced glycation and ameliorates early diabetic nephropathy in obese Zucker rats. Metabolism. 2009;58:1669-77.

17. Olivares A, Mendez JP, Cardenas M, Oviedo N, Palomino MA, Santos I, dkk. Pituitarytesticular axis function, biological to immunological ratio and charge isoform distribution of pituitary LH in male rats with experimental diabetes. Gen Comp Endocrinol. 2009;161(3):304-12.

18. Ballester J, Munoz MC, Dominguez J, Rigau T, Guinovart JJ, Rodriguez-Gil JE, dkk. Insulindependent diabetes affect testicular function by FSH and LH linked mechanisms. J Androl. 2004;25:706-19.

19. Aizawa K, Iemitsu M, Otsuki T, Maeda $S$, Miyauchi T, Mesaki N. Sex differences in steroidogenesis in skeletal muscle following a single bout of exercise in rats. J Appl Physiol. 2007;104:67-74.

20. Hambrecht R, Schulze PC, Gielen S, Linke A, Mobius-Winkler S, Erbs S, dkk. Effects of exercise training on insulin-like growth factor-1 expression in the skeletal muscle of non-cathectic patients with chronic heart failure. Eur J Cardiovasc Prev Rehabil. 2005;12(4):401-6. 